\title{
Photobacterium histaminum sp. nov., a Histamine-Producing Marine Bacterium
}

\author{
MASAYO OKUZUMI, ${ }^{1} \dagger$ AKIRA HIRAISHI, ${ }^{2}$ TAKESHI KOBAYASHI,${ }^{1}$ AND TATEO FUJII ${ }^{1 *}$ \\ Department of Food Science and Technology, Tokyo University of Fisheries, Konan, Minato-ku, Tokyo 108, ${ }^{1}$ and \\ Laboratory of Environmental Biotechnology, Konishi Co., Yokokawa, Sumida-ku, Tokyo 130, ${ }^{2}$ Japan
}

\begin{abstract}
A total of 23 strains of halophilic histamine-producing bacteria previously isolated from marine fish and seawater were studied phenotypically, genotypically, and phylogenetically. These organisms are facultatively anaerobic, gram-negative, short rods that are motile by means of one to three unsheathed polar flagella. They are mesophilic and nonluminescent, produce oxidase, utilize D-glucose but not D-mannitol as a carbon and energy source, and accumulate poly- $\beta$-hydroxybutyrate. The guanine-plus-cytosine contents of the DNAs are ca. $41 \mathrm{~mol} \%$. Genomic DNA hybridization experiments revealed that some of the isolates exhibited low levels of reassociation (less than $40 \%$ ) with previously described Photobacterium species. 16S rRNA gene sequence information confirmed the phylogenetic position of one of the isolates, strain $C-8^{T}$ ( $T=$ type strain), as a member of the genus Photobacterium. Therefore, we concluded that these organisms are members of a new species of the genus Photobacterium and propose the name Photobacterium histaminum sp. nov. for them. The type strain is strain C-8 (= JCM 8968).
\end{abstract}

Most of the histamine-producing bacteria that have been isolated previously as the causative agents of scombroid fish poisoning are members of the family Enterobacteriaceae; these bacteria include Citrobacter freundii (27), Enterobacter cloacae (21), Escherichia coli $(7,8)$, Hafnia alvei (8), Klebsiella pneumoniae (26), and Proteus morganii (Morganella morganii) (15, 16) strains. Some gram-positive bacteria, such as Clostridium perfringens, have also been reported to be histamine producers (34). On the other hand, less information about histamineproducing bacteria of marine origin has been available. During surveys of histamine-producing bacteria in marine fish and seawater, we isolated several strains of facultatively anaerobic, halophilic bacteria that produced appreciable amounts of histamine $(22,32,33)$. On the basis of growth temperature characteristics, these isolates were divided into two groups; the members of one group were psychrophilic strains that grew at $4^{\circ} \mathrm{C}$ but not at $40^{\circ} \mathrm{C}$, and the members of the other group were mesophiles which did not grow at $4^{\circ} \mathrm{C}$. We paid special attention to the mesophilic strains, because their ability to produce histamine was as great as that of $M$. morganii and because they appeared to belong to the genus Photobacterium on the basis of their phenotypic traits but could not be assigned to any previously described member of this genus.

In this study, we further characterized the new histamineproducing isolates phenotypically, genotypically, and phylogenetically. Phylogenetic relationships among members of marine genera, including the genus Photobacterium, have been inferred from partial 16S rRNA sequences consisting of about 600 bases (18). In this study, the phylogenetic position of a representative isolate was determined on the basis of almost complete $16 \mathrm{~S}$ ribosomal DNA (rDNA) sequences. On the basis of our data, we concluded that the isolates which we studied are members of a new species of the genus Photobacterium, for which we propose the name Photobacterium histaminum; strain C-8 is the type strain of this species.

\footnotetext{
* Corresponding author. Tokyo University of Fisheries, Konan, Minato-ku, Tokyo 108, Japan.

$\dagger$ Present address: Natori Co. Ltd., Toshima, Kita-ku, Tokyo 114, Japan.
}

\section{MATERIALS AND METHODS}

Bacterial strains and growth conditions. A total of 23 isolates previously obtained from different sources (31-33) were studied; 15 of these strains (C-4-1, C-4-2, C-5, C-6, C-7, $\mathrm{C}-12, \mathrm{C}-13, \mathrm{C}-15, \mathrm{C}-18, \mathrm{C}-19, \mathrm{C}-20, \mathrm{C}-21, \mathrm{C}-22, \mathrm{C}-23$, and $\mathrm{C}$-24) were isolated from coastal seawater obtained from Tokyo Bay, Japan (32), 5 strains (C-1, C-2, C-3, C-10, and $\mathrm{C}-11$ ) were isolated from seawater obtained from Sagami Bay, Japan (32), and 3 strains $\left(\mathrm{C}-8^{\mathrm{T}}\right.$ [ $\mathrm{T}=$ type strain], $\mathrm{C}-9$, and C-41) were isolated from skins of a labracoglossid fish (Labracoglassa argentiventris), a Japanese bluefish (Scombrops boops), and a sardine (Sardinops melanostictus) purchased from a fish market in Kanagawa, Japan, between June and August 1987 (33). The type strains of three Photobacterium species, Photobacterium phosphoreum ATCC 11040, Photobacterium angustum ATCC 25915, and Photobacterium leiognathi ATCC 25521, were obtained from the American Type Culture Collection, Rockville, Md., and were used as reference organisms. These strains were stabbed into $50 \%$ artificial seawater (ASW)peptone-yeast extract agar (0.5\% Polypeptone, $0.3 \%$ yeast extract, and $1.5 \%$ agar in $50 \%$ ASW [pH 7.0]) (22) and were maintained at $15^{\circ} \mathrm{C}$. Unless indicated otherwise, the inocula used for phenotypic tests were prepared from 18- to 24-h-old cultures in 50\% ASW-PMYG broth (0.5\% Polypeptone $0.25 \%$ meat extract, $0.25 \%$ yeast extract, and $0.1 \%$ glucose in $50 \%$ ASW [pH 7.0]) (22) and incubated at $30^{\circ} \mathrm{C}$.

Morphology. Cell morphology, Gram staining characteristics, and motility were studied as described previously (31). Flagella were observed by using negatively stained cells and electron microscopy (1). Accumulation of poly- $\beta$-hydroxybutyrate (PHB) was determined by the Sudan Black staining method (5).

Cultural, physiological, and biochemical characteristics. Hydrogen sulfide production was determined with SIM medium (Difco) after 6 days of incubation. Production of 2,3butandiol was determined by the method of Bullock (4) after 3 days of growth in medium supplemented with $2 \% \mathrm{NaCl}$. Bioluminescence was determined by examining colonies grown on plates containing Hidaka agar (9) (10 g of Polypeptone, $2 \mathrm{~g}$ of yeast extract, $3 \mathrm{~g}$ of glycerol, $15 \mathrm{~g}$ of agar, $750 \mathrm{ml}$ of ASW, $250 \mathrm{ml}$ of distilled water; [ $\mathrm{pH} 7.2]$ ). Cytochrome oxidase was 
detected by using commercially available test papers (Nissui Co., Tokyo, Japan). Starch hydrolysis was detected by covering the bacterial surface growth on a $2 \% \mathrm{NaCl}$-peptone-yeast extract-glucose ( $2 \% \mathrm{NaCl}-\mathrm{PYG})$ agar plate containing $0.1 \%$ soluble starch with Gram's iodine solution. Chitin decomposition was determined with a $2 \% \mathrm{NaCl}-\mathrm{PYG}$ agar plate containing $10 \%$ chitin. Alginate hydrolysis was determined with $75 \%$ ASW-yeast extract medium supplemented with $2 \%$ sodium alginate (24). Gelatin hydrolysis was detected by flooding the growth on a $2 \% \mathrm{NaCl}-\mathrm{PYG}$ agar plate containing $0.4 \%$ gelatin with acidic mercuric chloride (24). The $\mathrm{NaCl}$ requirement for optimal growth was determined by the method of Lee et al. (19). Utilization of organic compounds as carbon and energy sources was determined by the method of Baumann and Baumann (2). Most of the organic compounds used were added at a concentration of $1 \%(\mathrm{wt} / \mathrm{vol})$; the exceptions were ethanol (20 ml/liter), glycerol ( $20 \mathrm{ml} /$ liter $)$, and lactate $(16$ $\mathrm{ml} /$ liter). Growth was assayed turbidimetrically at $570 \mathrm{~nm}$ after 2,4 , and 6 days. Histamine contents in cultures were determined by high-performance liquid chromatography (HPLC) as described previously (30). Vibriostatic compound 0/129 (2,4diamino-6,7-diisopropyl pteridine phosphate) was applied as a filter paper disk (Daiichi Seiyaku). The test was performed with 50\% ASW-PMYG agar. All other phenotypic tests were performed by using standard protocols as described previously $(22,31)$.

DNA base composition and DNA-DNA homology. Genomic DNA was extracted and purified by the method of Marmur (20). DNA base composition (guanine-plus-cytosine [G+C] content) was determined by the HPLC method of KatayamaFujimura et al. (14). Escherichia coli DNA ( $\mathrm{G}+\mathrm{C}$ content, 51.6 mol\%) was obtained from Sigma Chemical Co., St. Louis, Mo., and was used as the standard. DNA-DNA pairing studies were performed by the quantitative dot blot hybridization method with photobiotin labeling and colorimetric detection $(6,12)$.

16S rRNA gene sequencing and phylogenetic analysis. The 16S rRNA gene was amplified by the PCR from proteasedigested cell lysates, using a commercial PCR kit, Taq DNA polymerase, and a pair of eubacterial consensus primers homologous or supplementary to positions 8 to 27 and 1492 to 1510 (29) (all positions indicated for 16S rRNA molecules are positions in the $E$. coli numbering system). The PCR products were subjected to chloroform-phenol treatment and ethanol precipitation and were purified by agarose gel electrophoresis. Detailed information concerning the PCR procedures used has been given elsewhere $(11,13)$. PCR-amplified, doublestranded $16 \mathrm{~S}$ rDNA was sequenced directly by the cycle sequencing method modified for automated fluorescence detection, and the reaction mixtures were analyzed with a Pharmacia model A.L.F. laser fluorescent DNA sequencer, as previously described $(11,13)$. Sequences were determined from overlapping sequence data by using the GENETYX computer program (Software Development Co., Tokyo, Japan). Nucleotide substitution rates ( $K_{\text {nuc }}$ values) (17) were determined and a distance matrix tree was constructed by the neighbor-joining method (23), using the CLUSTAL V program (10). Alignment gaps and unidentified base positions were not taken into consideration for the calculations.

Nucleotide sequence accession numbers. The $16 \mathrm{~S}$ rDNA sequences determined in this study have been deposited in the DDBJ, EMBL, GSDB, and NCBI nucleotide sequence databases under accession numbers D25308 to D25310. The accession numbers of the sequences used as references are as follows: Aeromonas hydrophila, X60404; E. coli, J01859; Listonella anguillara (Vibrio anguillarum), X16895; Photobacterium damsela (Listonella damsela), D11179, D11228, and



FIG. 1. Electron micrograph of a negatively stained cell of strain $\mathrm{C}-8^{\mathrm{T}}$. Bar $=1 \mu \mathrm{m}$.

D11277; Plesiomonas shigelloides, M59159; Shewanella putrefaciens, D11190, D11239, and D11288; Vibrio alginolyticus, X56576; Vibrio diazotrophicus, X56577; Vibrio fischeri, X74702; Vibrio hollisae, X56583; and Vibrio parahaemolyticus, X56580.

\section{RESULTS}

Morphology and cultural characteristics. The cells of all of the strains were gram-negative, asporogenous, motile, short rods that were 1.0 to $1.2 \mu \mathrm{m}$ wide and 2.2 to $2.5 \mu \mathrm{m}$ long (Fig. 1). Cells grown on solid media had one to three polar flagella which were not enclosed in a sheath, unlike the flagella of Vibrio species such as $V$. alginolyticus and $V$. fischeri. PHB granules accumulated in the cells, but fewer granules were found than are found in Photobacterium leiognathi ATCC $25521^{\mathrm{T}}$.

Colonies on $50 \%$ ASW-PMYG agar plates after $24 \mathrm{~h}$ of incubation at $30^{\circ} \mathrm{C}$ were entire, smooth, semitranslucent, ivory, and approximately 1 to $1.2 \mathrm{~mm}$ in diameter. After $48 \mathrm{~h}$ of incubation, the colonies were 2.0 to $2.5 \mathrm{~mm}$ in diameter; they were not bioluminescent.

Physiological and biochemical characteristics. The 23 strains which we studied were uniform in their physiological characteristics, with few exceptions. A summary of the phenotypic properties is shown in Table 1 . All 23 strains required $\mathrm{Na}^{+}$for growth (the optimum $\mathrm{NaCl}$ concentration was about $2 \%$ ) and were not able to grow in media lacking added $\mathrm{NaCl}$. Most of the 23 strains were able to grow at $40^{\circ} \mathrm{C}$ but not at $45^{\circ} \mathrm{C}$. All of the strains failed to grow at $4^{\circ} \mathrm{C}$. Optimal growth occurred at temperatures between 30 and $35^{\circ} \mathrm{C}$. All strains grew well at pH 4.5 to 9.0; the $\mathrm{pH}$ optima were between 6.0 and 7.0. Acid and gas were formed from D-glucose. All isolates produced $\mathrm{H}_{2} \mathrm{~S}$ in SIM medium, although in very small quantities. All strains formed histamine.

DNA base composition and DNA-DNA hybridization. Table 
TABLE 1. Characteristics of the histamine-producing bacteria

\begin{tabular}{|c|c|c|}
\hline Characteristic & 23 isolates $^{a}$ & Strain C-8 ${ }^{\mathrm{T}}$ \\
\hline Gram stain reaction & - & - \\
\hline Rod-shaped cells & + & + \\
\hline Spores & - & - \\
\hline Motility & + & + \\
\hline Sheathed polar flagella & - & - \\
\hline Acid produced from D-glucose & + & + \\
\hline Gas produced from D-glucose & + & + \\
\hline Catalase & + & + \\
\hline Oxidase & + & + \\
\hline Reduction of $\mathrm{NO}_{3}^{-}$to $\mathrm{NO}_{2}^{-}$ & + & + \\
\hline $\begin{array}{l}\text { Accumulation of PHB coupled with the } \\
\text { inability to utilize } \beta \text {-hydroxybutyrate }\end{array}$ & + & + \\
\hline Production of 2,3-butandiol & + & + \\
\hline Production of $\mathrm{H}_{2} \mathrm{~S}$ & + & + \\
\hline \multicolumn{3}{|l|}{ Hydrolysis of: } \\
\hline Starch & + & + \\
\hline Chitin & + & + \\
\hline Alginate & - & - \\
\hline Gelatin & - & - \\
\hline Luminescence & - & - \\
\hline Susceptibility to vibriostatic agent $0 / 129$ & + & + \\
\hline $\mathrm{Na}^{+}$required for growth & + & + \\
\hline \multicolumn{3}{|l|}{ Growth in the presence of: } \\
\hline $0 \% \mathrm{NaCl}$ & - & - \\
\hline $2 \% \mathrm{NaCl}$ & + & + \\
\hline $6 \% \mathrm{NaCl}$ & + & + \\
\hline $8 \% \mathrm{NaCl}$ & - & - \\
\hline \multicolumn{3}{|l|}{ Growth at: } \\
\hline $4^{\circ} \mathrm{C}$ & - & - \\
\hline $20^{\circ} \mathrm{C}$ & + & + \\
\hline $30^{\circ} \mathrm{C}$ & + & + \\
\hline $40^{\circ} \mathrm{C}$ & $\mathrm{d}$ & + \\
\hline \multicolumn{3}{|l|}{ Utilization of: } \\
\hline $\begin{array}{l}\text { Acetate, succinate, fumarate, D-ribose, } \\
\text { D-fructose, D-glucose, D-mannose, } \\
\text { D-galactose, maltose, cellobiose, } \\
\text { melibiose, trehalose, L-aspartate, } \\
\text { L- } \alpha \text {-alanine, L-glutamate, L-proline, } \\
\text { L-serine, L-threonine, glycerol, } \\
\text { hippurate }\end{array}$ & + & + \\
\hline $\begin{array}{l}\text { Valerate, isovalerate, DL-lactate, } \\
\text { pyruvate, DL-malate, L-tartrate, } \\
\text { citrate, malonate, D-gluconate, D- } \\
\text { glucuronate, D-xylose, L-arabinose, } \\
\text { L-rhamnose, lactose, salicine, } \\
\text { sucrose, D-galacturonate, D- } \\
\text { mannitol, D-sorbitol, ethanol, } n \text { - } \\
\text { propanol, D- } \alpha \text {-alanine, } \beta \text {-alanine, } \\
\text { L-leucine, L-arginine, } \gamma \text { - } \\
\text { aminobutyrate, L-citrulline, glycine, } \\
\text { L-histidine, L-ornithine, betaine }\end{array}$ & 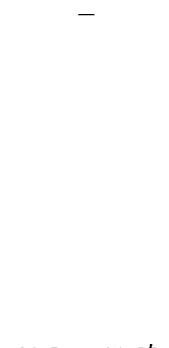 & - \\
\hline $\mathrm{G}+\mathrm{C}$ content of DNA (mol\%) & $41.3 \sim 41.8^{b}$ & 41.6 \\
\hline
\end{tabular}

2 shows the DNA base compositions and levels of DNA-DNA relatedness among the organisms studied. The $\mathrm{G}+\mathrm{C}$ contents of the isolates (strains C-3, C- $8^{\mathrm{T}}$, and C-41) ranged from 41.3 to $41.8 \mathrm{~mol} \%$, values which are similar to the $\mathrm{G}+\mathrm{C}$ contents of some previously described Photobacterium species. Genomic DNA hybridization experiments performed with labeled DNAs from strain $\mathrm{C}-8^{\mathrm{T}}$ and Photobacterium phosphoreum ATCC $11040^{\mathrm{T}}$ revealed that the new isolates were closely related to each other but exhibited relatively low levels of hybridization (less than $40 \%$ ) with the three previously described species Photobacterium species, Photobacterium phosphoreum, Photobacterium angustum, and Photobacterium leiognathi. Among the strains of previously described species used for comparison, Photobacterium leiognathi ATCC $25521^{\mathrm{T}}$ exhibited the highest level of homology to strain $\mathrm{C}-8^{\mathrm{T}}$.

$16 \mathrm{~S}$ rDNA sequence comparisons. The PCR-amplified $16 \mathrm{~S}$ rDNA sequences of one of our isolates, strain $\mathrm{C}-8^{\mathrm{T}}$, and the three previously described Photobacterium species were determined to obtain more information about the interspecies relationships of these organisms. The rDNA fragments used, excluding the PCR primer-annealing regions, consisted of continuous nucleotide stretches from positions 28 to 1491 that were 1,470 to 1,476 residues long. The $16 \mathrm{~S}$ rDNA sequences of the test organisms were compared with the sequences of eight reference species belonging to the gamma subclass of the Proteobacteria. Table 3 shows the evolutionary distance $\left(K_{\text {nuc }}\right)$ values which we calculated for the 1,367 positions of all of the sequences which could be aligned. The corrected distance values obtained for strain $\mathrm{C}-8^{\mathrm{T}}$ and the previously described Photobacterium species ranged from 0.0271 to 0.0446 . The evolutionary distances between strain $\mathbf{C}-8^{\mathbf{T}}$ and the other species compared were more than 0.0541 . On the basis of the $K_{\text {nuc }}$ values shown in Table 3 , a distance matrix tree was reconstructed by the neighbor-joining method (Fig. 2).

\section{DISCUSSION}

We found that the new isolates which we studied are members of a phenotypically homogeneous group that can be regarded as a single species. These organisms are halophilic, facultatively anaerobic chemoheterotrophs that have gramnegative, nonsporeforming, rod-shaped cells which are motile by means of unsheathed polar flagella. They are also oxidase positive, accumulate $\mathrm{PHB}$, utilize glucose but not mannitol as a carbon source, and have genomic DNA G+C contents of ca. $41 \mathrm{~mol} \%$. On the basis of these characteristics, the isolates should be considered members of the genus Photobacterium (3). Two characteristics of the isolates, unsheathed polar flagella and PHB accumulation, distinguish them from members of a morphologically and physiologically similar genus, the genus Vibrio. Also, our isolates are clearly differentiated from

TABLE 2. Levels of DNA-DNA reassociation between the histamine-producing strains and three Photobacterium species

\begin{tabular}{|c|c|c|c|c|c|}
\hline \multirow{2}{*}{ Source of unlabeled DNA } & \multirow{2}{*}{$\begin{array}{c}\mathrm{G}+\mathrm{C} \text { content of DNA } \\
(\mathrm{mol} \%)\end{array}$} & \multicolumn{4}{|c|}{ \% Relatedness to labeled DNA from: } \\
\hline & & $\overline{C-8^{T}}$ & ATCC $11040^{\mathrm{T}}$ & ATCC $25521^{\mathrm{T}}$ & ATCC $25915^{\mathrm{T}}$ \\
\hline \multicolumn{6}{|l|}{ Histamine-producing strains } \\
\hline $\mathrm{C}-8^{\mathrm{T}}$ & 41.6 & 100 & 29 & 40 & 19 \\
\hline $\mathrm{C}-3$ & 41.8 & 99 & 30 & $\mathrm{NT}^{a}$ & NT \\
\hline Photobacterium phosphoreum ATCC $11040^{\mathrm{T}}$ & 40.8 & 31 & 100 & NT & NT \\
\hline Photobacterium leiognathi ATCC $25521^{\mathrm{T}}$ & 41.9 & 36 & 32 & 100 & NT \\
\hline Photobacterium angustum ATCC $25915^{\mathrm{T}}$ & 41.0 & 34 & 40 & NT & 100 \\
\hline
\end{tabular}

${ }^{a}$ NT, not tested. 
TABLE 3. Evolutionary distance $\left(K_{\text {nuc }}\right)$ values for $16 \mathrm{~S}$ rDNAs and rRNAs of Photobacterium species, strain C- $8^{\mathrm{T}}$, and related organisms

\begin{tabular}{|c|c|c|c|c|c|c|c|c|c|c|c|c|}
\hline \multirow[b]{2}{*}{ Organism } & \multicolumn{12}{|c|}{$K_{\text {nuc }}$ value with: } \\
\hline & 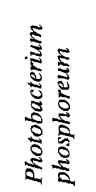 & 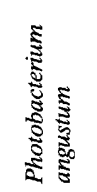 & 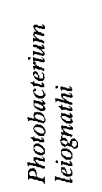 & 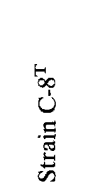 & 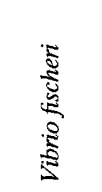 & 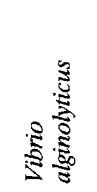 & 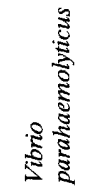 & 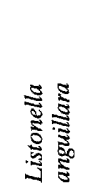 & 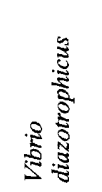 & 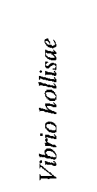 & 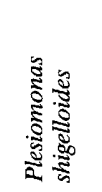 & 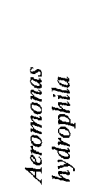 \\
\hline Photobacterium angustum & 0.0154 & & & & & & & & & & & \\
\hline Photobacterium leiognathi & 0.0263 & 0.0249 & & & & & & & & & & \\
\hline Strain C-8 $8^{\mathrm{T}}$ & 0.0439 & 0.0446 & 0.0271 & & & & & & & & & \\
\hline Vibrio fischeri & 0.0527 & 0.0527 & 0.0468 & 0.0563 & & & & & & & & \\
\hline Vibrio alginolyticus & 0.0571 & 0.0490 & 0.0461 & 0.0541 & 0.0424 & & & & & & & \\
\hline Vibrio parahaemolyticus & 0.0591 & 0.0578 & 0.0563 & 0.0636 & 0.0512 & 0.0198 & & & & & & \\
\hline Listonella anguillara & 0.0636 & 0.0600 & 0.0622 & 0.0702 & 0.0475 & 0.0322 & 0.0410 & & & & & \\
\hline Vibrio diazotrophicus & 0.0622 & 0.0600 & 0.0607 & 0.0680 & 0.0578 & 0.0351 & 0.0424 & 0.0337 & & & & \\
\hline Vibrio hollisae & 0.0629 & 0.0644 & 0.0563 & 0.0549 & 0.0753 & 0.0490 & 0.0541 & 0.0636 & 0.0600 & & & \\
\hline Plesiomonas shigelloides & 0.0849 & 0.0892 & 0.0871 & 0.0878 & 0.0819 & 0.0849 & 0.0922 & 0.0929 & 0.0863 & 0.0966 & & \\
\hline Aeromonas hydrophila & 0.0966 & 0.1024 & 0.0944 & 0.0966 & 0.0995 & 0.0988 & 0.1053 & 0.0958 & 0.1039 & 0.0995 & 0.0856 & \\
\hline Escherichia coli & 0.0900 & 0.0922 & 0.0922 & 0.0966 & 0.0892 & 0.0885 & 0.0980 & 0.0988 & 0.0914 & 0.0973 & 0.0593 & 0.0922 \\
\hline
\end{tabular}

members of the genera Aeromonas and Plesiomonas by their salt requirement, DNA base ratios, and other properties.

However, phenotypic and genotypic studies revealed that the new isolates cannot be assigned to any of the previously described species of the genus Photobacterium. The new isolates differ from Photobacterium phosphoreum in growing at $35^{\circ} \mathrm{C}$ but not at $4^{\circ} \mathrm{C}$, producing amylase, and utilizing acetate and L-proline. They differ from Photobacterium angustum in producing gas and 2,3-butandiol from glucose and utilizing cellobiose, melibiose, and hippurate but not xylose, pyruvate, or gluconate. And they differ from Photobacterium leiognathi in producing gas from glucose and utilizing pyruvate, gluconate, and lactate. In addition, the new isolates are characterized by their ability to produce large amounts of histamine. Also, the new isolates exhibit levels of genomic DNA hybridization with the previously described Photobacterium species of less than $40 \%$. The hybridization values which we obtained are sufficient to separate these organisms from Photobacterium phosphoreum, Photobacterium leiognathi, and Photobacterium angustum at the species level in light of the species concept standardized on the basis of DNA-DNA reassociation values (28). Recently, Listonella damsela was transferred to the genus Photobacterium as Photobacterium damsela (25) on the basis of phenotypic data. Since Photobacterium damsela was not included as a reference organism in this study, we could not

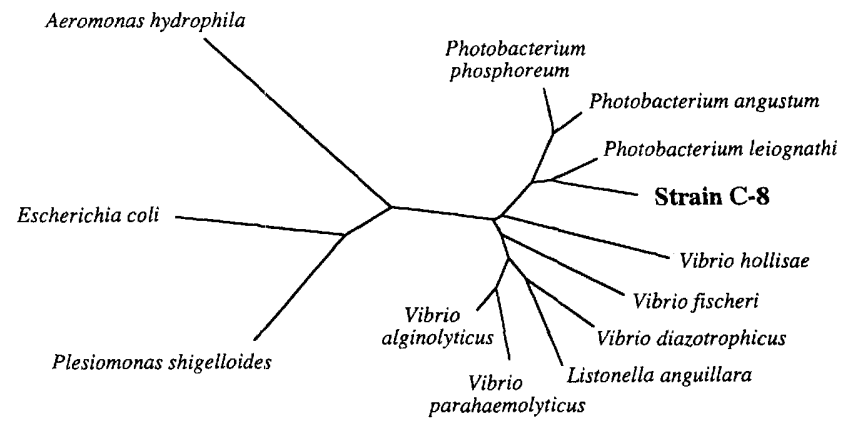

FIG. 2. Unrooted distance matrix tree showing the phylogenetic positions of strain $\mathrm{C}-8^{\mathrm{T}}$ and members of the gamma subclass of the Proteobacteria. Bar $=0.02 K_{\text {nuc }}$. compare our isolates with this species genotypically. However, the information available for Photobacterium damsela indicates that there are some phenotypic differences (e.g., amylase production, utilization of lactate and pyruvate) between this species and our isolates.

The results of phylogenetic analyses performed with $16 \mathrm{~S}$ rRNA gene sequence information support the conclusions described above and further clarify the taxonomic and phylogenetic position of the new isolates among members of the genus Photobacterium and related genera. The phylogenetic tree in Fig. 2 shows that strain $\mathrm{C}-8^{\mathrm{T}}$ forms a cluster with all previously described members of the genus Photobacterium except Photobacterium damsela, but is located in a deeply branched, separate lineage within this cluster. Recent research on the phylogeny of marine enterobacteria inferred from partial 16S rRNA sequences has shown that Photobacterium damsela, together with Vibrio costicola and $V$. hollisae, belongs to a lineage different from the Photobacterium cluster (18). We compared the $16 \mathrm{~S}$ rDNA sequence of strain C- $8^{\mathrm{T}}$ with the partial sequence of Photobacterium damsela and found that there were 10 base differences in the 535 positions compared, corresponding to a level of similarity of $98.1 \%$. This value is low enough to warrant placement of the two organisms in separate species. Since the new isolates are similar to a marine bacterium belonging to the gamma subclass, Shewanella putrefaciens, in sulfide production, the 16S rDNA sequence of strain C- $8^{\mathrm{T}}$ was also compared with the available partial sequence of that species. The level of similarity between the two sequences was only $89.2 \%$ (532 positions were compared), suggesting that these organisms belong to different genera. A previous report has shown that the position of $S$. putrefaciens is far from the position of the Photobacterium cluster on the 16S rRNA sequence-based phylogenetic tree (18). On the basis of phenotypic, genotypic, and phylogenetic data, it is logical to conclude that the isolates which we studied should be classified as members of a new species of the genus Photobacterium. We propose the name Photobacterium histaminium sp. nov. for our isolates because of their ability to produce histamine in scombroid fish.

Description of Photobacterium histaminum sp. nov. Photobacterium histaminum (his.ta.mi'num. N.L.n. histaminum, histamine). Gram-negative, asporogenous, short, rod-shaped cells with rounded ends that are 1.0 to $1.2 \mu \mathrm{m}$ wide and 2.2 to 2.5 
$\mu \mathrm{m}$ long. Motile by means of one to three polar flagella. PHB accumulates in cells. Colonies on ordinary nutrient agar having an ASW base are entire, smooth, semitranslucent, nonluminescent, and ivory; they are 1.0 to $1.2 \mathrm{~mm}$ in diameter after 24 $\mathrm{h}$ of incubation at $30^{\circ} \mathrm{C}$. Halophilic and mesophilic. Best growth occurs at an $\mathrm{NaCl}$ concentration of ca. $2 \%$. No growth occurs in the absence of $\mathrm{NaCl}$. The optimal temperature for growth is between 30 and $35^{\circ} \mathrm{C}$. No growth occurs at 4 or $45^{\circ} \mathrm{C}$. Growth occurs at $\mathrm{pH} 4.5$ to 9.0 , and the optimum $\mathrm{pH}$ is 6.0 to 7.0. Facultatively anaerobic chemoorganotroph having both respiratory and fermentative types of metabolism. Oxidase and catalase positive. Acid and gas are produced from D-glucose and many other carbohydrates. Nitrate is reduced to nitrite. Amylase and chitinase are produced. Neither gelatin nor alginate is hydrolyzed. Histamine is produced. Susceptible to vibriostatic agent 0/129 (2,4-diamino-6,7-diisopropyl pteridine). The following compounds are utilized as sole carbon and energy sources: acetate, succinate, fumarate, D-ribose, D-fructose, D-glucose, D-mannose, D-galactose, maltose, cellobiose, melibiose, trehalose, glycerol, L-aspartate, L- $\alpha$-alanine, L-glutamate, L-proline, L-serine, L-threonine, and hippurate. The following compounds are not utilized: valerate, isovalerate, DL-lactate, pyruvate, DL-malate, L-tartrate, citrate, malonate, D-gluconate, D-glucronate, D-xylose, L-arabinose, Lrhamnose, lactose, salicine, sucrose, D-galacturonate, D-mannitol, D-sorbitol, ethanol, $n$-propanol, D- $\alpha$-alanine, $\beta$-alanine, L-leucine, L-arginine, $\gamma$-aminobutyrate, L-citrulline, glycine, Lhistidine, L-ornithine, and betaine. The $\mathrm{G}+\mathrm{C}$ content of the DNA ranges from 41.3 to $41.8 \mathrm{~mol} \%$.

Habitat: seawater and marine fish.

The type strain is strain C-8, which has been deposited in the Japan Collection of Microorganisms as strain JCM 8968.

\section{ACKNOWLEDGMENT}

We thank R. Yoguchi (Department of Food Science and Technology, Tokyo University of Fisheries) for earlier contributions to this study.

\section{REFERENCES}

1. Allen, R. D., and P. Baumann. 1971. Structure and arrangement of flagella in species of the genus Beneckea and Photobacterium fischeri. J. Bacteriol. 107:295-302.

2. Baumann, P., and L. Baumann. 1981. The marine Gram-negative eubacteria, p. 1302-1331. In M. P. Starr, H. Stolp, H. G. Trüper, A. Balows, and H. G. Schlegel (ed.), The prokaryotes, vol. 2. Springer-Verlag, New York.

3. Baumann, P., and L. Baumann. 1984. Genus II. Photobacterium, p. 539-545. In N. R. Krieg and J. G. Holt (ed.), Bergey's manual of systematic bacteriology, vol. 1. The Williams \& Wilkins Co. Baltimore.

4. Bullock, G. L. 1961. A schematic outline for the presumptive identification of bacterial disease of fish. Prog. Fish-Cult. 23:147151.

5. Burdon, K. L. 1946. Fatty material in bacteria and fungi revealed by staining dried, fixed slide preparations. J. Bacteriol. 52:665678.

6. Ezaki, T., S. Dejsirilert, H. Yamamoto, N. Takeuchi, S. Liu, and E. Yabuuchi. 1988. Simple and rapid genetic identification of Legionella species with photobiotin-labeled DNA. J. Gen. Appl. Microbiol. 34:191-199.

7. Ferncik, M. 1970. Formation of histamine during bacterial decarboxylation of histidine in the flesh of some marine fishes. J. Hyg Epidemiol. Microbiol. Immunol. (Prague) 14:52-60.

8. Havelka, B. 1967 . Role of the Hafnia bacteria in the rise of histamine in tuna fish meat. Cesk. Hyg. 12:343-352.

9. Hidaka, T. 1965 . On the specificity of mineral requirement of marine bacteria. Mem. Fac. Fish. Kagoshima Univ. 14:127-128.

10. Higgins, D. G., A. J. Bleasby, and R. Fuchs. 1993. CLUSTAL V: improved software for multiple sequence alignment. Comp. Appl. Biosci. 8:189-191.

11. Hiraishi, A. 1992. Direct automated sequencing of $16 \mathrm{~S}$ rDNA amplified by polymerase chain reaction from bacterial cultures without DNA purification. Lett. Appl. Microbiol. 15:210-213.

12. Hiraishi, A., Y. Hoshino, and T. Satoh. 1991. Rhodoferax fermentans gen. nov., sp. nov., a phototrophic purple nonsulfur bacterium previously referred to as the "Rhodocyclus gelatinosus-like" group. Arch. Microbiol. 155:330-336.

13. Hiraishi, A., Y. K. Shin, Y. Ueda, and J. Sugiyama. 1994. Automated sequencing of PCR-amplified 16S rDNA on "Hydrolink" gels. J. Microbiol. Methods 19:145-154.

14. Katayama-Fujimura, Y., Y. Komatsu, H. Kuraishi, and T. Kanako. 1984. Estimation of DNA base composition by high performance liquid chromatography of its nuclease P1 hydrolysate. Agric. Biol. Chem. 48:3169-3172.

15. Kawabata, T., K. Ishizuka, T. Miura, and T. Sasaki. 1956. Studies on the food poisoning associated with putrefaction of marine products. VIII. An outbreak of allergy-like food poisoning caused by "sashimi" of Parathunus mebachi and the isolation of causative bacteria. Bull. Jpn. Soc. Sci. Fish. 22:41-47.

16. Kimata, M., and A. Kawai. 1953. A new species of bacterium which produces a large amount of histamine on fish meats found in spoiled fresh fish. Mem. Res. Inst. Food Sci. Kyoto Univ. 6:1-2.

17. Kimura, M. 1980. A simple method for estimating evolutionary rates of base substitution through comparative studies of nucleotide sequences. J. Mol. Biol. 16:111-120.

18. Kita-Tsukamoto, K., H. Oyaizu, K. Nanba, and U. Simidu. 1993. Phylogenetic relationships of marine bacteria, mainly members of the family Vibrionaceae, determined on the basis of 16S rRNA sequences. Int. J. Syst. Bacteriol. 43:8-19.

19. Lee, J. V., M. S. Hendrie, and J. M. Shewan. 1979. Identification of Aeromonas, Vibrio and related organisms, p. 151-166. In F. A. Skinner and D. W. Lovelock (ed.), Identification methods for microbiologists. Academic Press, London.

20. Marmur, J. 1961. A procedure for the isolation of deoxyribonucleic acid from micro-organisms. J. Mol. Biol. 3:208-218.

21. Niven, C. F., M. B. Jeffery, and D. A. Corlett. 1981. Differential plating medium for quantitative detection of histamine-producing bacteria. Appl. Environ. Microbiol. 41:321-322.

22. Okuzumi, M., S. Okuda, and M. Awano. 1981. Isolation of psychrophilic and halophilic histamine-forming bacteria from Scomber japonicus. Bull. Jpn. Soc. Sci. Fish. 47:1591-1598.

23. Saitou, N., and M. Nei. 1987. The neighbor-joining method: a new method for reconstructing phylogenetic trees. Mol. Biol. Evol. 4:406-425.

24. Skerman, V. B. D. 1967. A guide for the identification of the genera of bacteria. The Williams \& Wilkins Co., Baltimore.

25. Smith, S. K., D. C. Sutton, J. A. Fuerst, and J. L. Reichelt. 1991. Evaluation of the genus Listonella and reassignment of Listonella damsela (Love et al.) MacDonell and Colwell to the genus Photobacterium as Photobacterium damsela comb. nov. with emended description. Int. J. Syst. Bacteriol. 41:529-534.

26. Taylor, S. L., L. S. Guthertz, M. Leatherwood, and E. R. Leiber. 1979. Histamine production by Klebsiella pneumoniae and an incident of scombroid fish poisoning. Appl. Environ. Microbiol. 37:274-278.

27. Taylor, S. L., and M. W. Speckhard. 1983. Isolation of histamineproducing bacteria from frozen tuna. Mar. Fish. Rev. 45:35-39.

28. Wayne, L. G., D. J. Brenner, R. R. Colwell, P. A. D. Grimont, O. Kandler, M. I. Krichevsky, L. H. Moore, W. E. C. Moore, R. G. E. Murray, E. Stackebrandt, M. P. Starr, and H. G. Truper. 1987. Report of the Ad Hoc Committee on Reconciliation of Approaches to Bacterial Systematics. Int. J. Syst. Bacteriol. 37:463464.

29. Weisburg, W. G., S. M. Barns, D. A. Pelletier, and D. J. Lane. 1991. 16S ribosomal DNA amplification for phylogenetic study. J. Bacteriol. 173:697-703.

30. Yamanaka, H., and M. Matsumoto. 1989. Simultaneous determination of polyamines in red meat fishes by high performance liquid chromatography and evaluation of freshness. J. Food Hyg. Soc. Jpn. 30:396-400. 
31. Yoguchi, R. 1990. Ph.D. thesis. Tokyo University of Fisheries, Tokyo.

32. Yoguchi, R., M. Okuzumi, and T. Fujii. 1990. Seasonal variation in numbers of mesophilic and halophilic histamine-forming bacteria in inshore of Tokyo Bay and Sagami Bay. Nippon Suisan Gakkaishi 56:1467-1472.
33. Yoguchi, R., M. Okuzumi, and T. Fujii. 1990. Seasonal variation in numbers of mesophilic and halophilic histamine-forming bacteria on marine fish. Nippon Suisan Gakkaishi 56:1473-1479.

34. Yoshinaga, D. H., and H. A. Frank. 1982. Histamine-producing bacteria in decomposing skipjack tuna (Katswonus pelamis). Appl. Environ. Microbiol. 44:447-452. 